\title{
Article/Artigo
}

\section{Production of anti-Cryptosporidium polyclonal antibodies and standardization of direct immunofluorescence for detecting oocysts in water}

\author{
Produção de anticorpos policlonais anti-Cryptosporidium e padronização da imunofluorescência \\ direta para a detecção de oocistos na água
}

\begin{abstract}
Silvia Cristina Osaki ${ }^{1,2}$, Adriana Oliveira Costa ${ }^{3}$, Ludmilla Della Coletta Troiano ${ }^{1}$, Ernesto Renato Kruger ${ }^{1,4}$, Juliana Tracz Pereira ${ }^{5}$, Nelson Luis Mello Fernandes ${ }^{1,2}$, Márcia Benedita de Oliveira Silva ${ }^{6}$ and Vanete Thomaz Soccol ${ }^{1}$
\end{abstract}

\begin{abstract}
Introduction: The production of anti-Cryptosporidium polyclonal antibodies and its use in direct immunofluorescence assays to determine the presence of Cryptosporidium in water are described in the present work. Methods: Two rabbits were immunized with soluble and particulate antigens from purified Cryptosporidium oocysts. The sera produced were prepared for immunoglobulin $\mathrm{G}$ extraction, which were then purified and conjugated with fluorescein isothiocyanate (FITC). Slides containing known amounts of oocysts were prepared to determine the sensitivity of the technique. To test the specificity, slides containing Giardia duodenalis cysts were prepared. Results: The conjugate was successfully used in water samples experimentally contaminated with Cryptosporidium oocysts, and it was possible to detect up to five oocysts/spot, corresponding to contamination of 250 oocysts $/ \mathrm{mL}$. Conclusions: The three immunizations performed in the rabbits were enough to produce antibodies against Cryptosporidium, the standard direct immunofluorescence assay permitted the detection of five oocysts in $20 \%$ of the samples, and no cross-reaction with Giardia duodenalis cysts occurred.
\end{abstract}

Keywords: Polyclonal antibodies. Direct immunofluorescence. Oocysts. Water.

\section{RESUMO}

Introdução: A produção de anticorpos policlonais anti-Cryptosporidium e sua utilização na imunofluorescência para determinar a presença de Cryptosporidium em água são descritas no presente trabalho. Métodos: Dois coelhos foram imunizados com antígeno solúvel e particulado provenientes de oocistos purificados de Cryptosporidium. O soro produzido foi preparado para a extração de imunoglobulinas $\mathrm{G}$, que foram purificadas e conjugadas com isotiocianato de fluoresceína (FITC). Lâminas contendo quantidades conhecidas de oocistos foram preparadas para determinar a sensibilidade da técnica. Para testar a especificidade foram preparadas lâminas contendo cistos de Giardia duodenalis. Resultados: O conjugado foi usado com sucesso em amostras de água contaminadas experimentalmente com oocistos de Cryptosporidium, sendo capaz de detectar até cinco oocistos/spots que corresponde a uma contaminação de 250 oocistos/mL. Conclusões: As três imunizações realizadas nos coelhos foram suficientes para produção de anticorpos contra Cryptosporidium; a reação de imunofluorescência direta padronizada permitiu a detecção de cinco oocistos em $20 \%$ das amostras; não houve reação cruzada com cistos de Giardia duodenalis.

Palavras-chaves: Anticorpos policlonais. Imunofluorescência direta. Oocistos. Água.

1. Programa de Pós-Graduação em Processos Biotecnológicos e Biotecnologia, Divisão de Biotecnologia, Universidade Federal do Paraná, Curitiba, PR. 2. Disciplina de Ciências Agrárias/Epidemiologia, Universidade Federal do Paraná, Palotina, PR. 3. Departamento de Análises Clínicas e Toxicológicas, Faculdade de Farmácia, Universidade Federal de Minas Gerais, Belo Horizonte, MG. 4. Instituto Marcos Enrietti, Secretaria de Agricultura do Estado do Paraná, Curitiba, PR. 5. Departamento de Química, Instituto Federal do Paraná, Paranaguá, PR. 6. Disciplina de Parasitologia, Instituto de Ciências Biológicas e Naturais, Universidade Federal do Triângulo Mineiro, Uberaba, MG.

Address to: Dra. Vanete Thomaz Soccol. PPGBIOTEC/Div. Biotecnol/UFPR. Rua Cel. Francisco H. dos Santos 100/2 ${ }^{\circ}$ andar, Centro Politécnico, Prédio de Administração, 81531-990 Curitiba, PR, Brasil. Phone: 554133613272

e-mail: vanete.soccol@pq.cnpq.br

Received in 22/02/2011

Accepted in 09/06/2011

\section{INTRODUCTION}

The direct immunofluorescence assay (DIF) for detecting Cryptosporidium was developed in the 1980s and showed advantages in relation to the technique used up until that point, which involved floating with a zinc sulfate solution and Lugol staining ${ }^{1}$. When compared with acid fuchsin staining, the immunofluorescence assay technique shows greater sensitivity and specificity ${ }^{2}$.

One of the problems in using DIF in water samples is the presence of a large number of organic and inorganic substances capable of binding to antibodies and producing a false-positive result ${ }^{3}$. This problem can be minimized by establishing a purifying stage; the purpose of which is to eliminate the particles that can bind to marked antibodies producing fluorescence that could confuse the less-experienced technician.

This technique and others that use immunofluorescent methods are not able to identify the Cryptosporidium species, the genotype and specific hosts ${ }^{4}$, but are still very important in epidemiological studies and in the evaluation of the water following treatment. Additionally, methods 1,622 and 1,623 of the American Environment Protection Agency, developed for monitoring Cryptosporidium in water, require a final stage that involves fluorescent monoclonal antibodies capable of staining the membrane of Cryptosporidium oocysts.

Considering the high cost for performing methods 1,622 or 1,623 , the proposal of the present work was to produce polyclonal antibodies that can be used in immunofluorescence assays in water samples from impounding or treated water, aimed at determining contamination levels by Cryptosporidium oocysts.

\section{METHODS}

\section{Antigenic extract preparation}

Cryptosporidium parvum oocysts were purified from calf feces by sucrose gradient as previously described ${ }^{7}$. A total of $10^{8}$ oocysts diluted in $10 \mathrm{~mL}$ of 
phosphate buffered saline (PBS), $\mathrm{pH} 7.2$, were disrupted by sonication at $60 \mathrm{~Hz}$ (five cycles/min in an ice bath followed by a 1-min rest). The material was observed under phase contrast microscopy to ensure the efficacy of sonication to rupture the membrane. The extract was centrifuged for $30 \mathrm{~min}$ at $9,000 \mathrm{x} g$ at $4^{\circ} \mathrm{C}$, and the soluble antigen (supernatant) and particulate antigen (sediment) were separated into two aliquots. The protein concentration was determined by the Bradford method $^{8}$ using $1 \mathrm{mg} / \mathrm{mL}$ bovine serum albumin (BSA) as standard. Absorbance readings were performed using a 595-nm filter.

\section{Immunization}

Two male New Zealand rabbits, approximately 7 months old, were used for immunization after they were submitted to an adaptation period of 30 days.

Three subcutaneous immunizations were administered in the scapular area of each rabbit, alternating between the right and left sides. The first dosage of the antigenic extracts contained $1.25 \mathrm{mg}$ and $0.85 \mathrm{mg}$ of the soluble and particulate antigen, respectively, and complete Freund's adjuvant (Sigma Chemical Company). The second immunization was performed after 15 days, using the antigenic extract in the same concentration described before and incomplete Freund's adjuvant (Sigma Chemical Company). The third immunization was repeated 15 days after the application of the second dosage, using identical concentrations of antigenic extract and adjuvant. Blood collections were performed on days $0,15,30$, $45,60,90$, and 120 to determine the antibody titers. The production blood collections were performed on days 45,60 , and 75 , and the sera were stored at $-20^{\circ} \mathrm{C}$ until use.

\section{Titering sera samples}

The immunoenzymatic assay (enzyme-linked immunosorbent assay, ELISA) was used to determine the kinetics of antiCryptosporidium antibody production. The protocol adopted for the experiment followed that proposed by Frost et al. ${ }^{9}$

Briefly, flat-bottom plates (Immulon 2, Dynatech Laboratories, Inc.) were adsorbed with soluble antigen or particulate antigen at four different concentrations $(250,500,1,000$, and $1,500 \mathrm{ng})$ diluted in a carbonate buffer $(0.05 \mathrm{M}, \mathrm{pH} 9.6)$. The rabbit sera were diluted 1:100, $1: 200,1: 400,1: 800$, and 1:1600 in incubation buffer (PBS; $0.25 \%$ casein; $0.05 \%$ Tween 20 ). The rabbit anti-IgG immunoglobulin conjugated to the enzyme peroxidase (Sigma Chemical Company, A-0545) diluted at 1:2500 and 1:5000 was added, and the enzymatic activity was revealed using orthophenylenediamine solution (OPD) diluted in substrate buffer ( $4 \mathrm{mg}$ of $\mathrm{OPD}+10.5 \mathrm{~mL}$ of citrate buffer $\mathrm{pH} 5.0+4 \mu \mathrm{L}$ of $\mathrm{H}_{2} \mathrm{O}_{2}$ ). The reaction was interrupted using $50 \mathrm{~L}$ of $5 \% \mathrm{H}_{2} \mathrm{SO}_{4}$. The negative control of the reaction was performed using the serum collected from the same rabbit on day 0 of the experiment, prior to inoculation with the antigenic extract. The serum collected on day 45 of the experiment was used as a positive control, in accordance with the proposal of Fernandes et al. ${ }^{10}$

The absorbance readings of the ELISA test were performed in the microplate reader (BIORAD Model 550) using a $492 \mathrm{~nm}$ wavelength filter.

\section{Glycoprotein extraction}

The extraction of glycoproteins was performed according to method proposed by Penha ${ }^{11}$. A pool of sera collected on days 30, 45, and 60 was centrifuged at $3,700 \mathrm{xg}$ for $5 \mathrm{~min}$ at $4{ }^{\circ} \mathrm{C}$. The supernatant was harvested, and $5 \%$ dextran was added in the proportion of $1.25 \mathrm{~mL}$ of dextran to $25 \mathrm{~mL}$ of serum, drop by drop, under stirring at room temperature. The mixture was maintained for $30 \mathrm{~min}$ at room temperature, stirring every $10 \mathrm{~min}$. An $11.1 \% \mathrm{CaCl}_{2}$ solution was added, drop by drop, under agitation in an ice bath, up to a final concentration of $1 \%$. The mixture was allowed to stand for $30 \mathrm{~min}$ in the ice bath and was then centrifuged at $14,400 \mathrm{x} g$ for $15 \mathrm{~min}$. The supernatant was separated, and the same volume of PBS $\mathrm{pH} 7.2$ was added. Twice the volume of saturated ammonium sulphate ( $\mathrm{pH} 7.6$ ) was added, and the mixture was left under slow magnetic stirring for 1 h at room temperature. Following precipitation of immunoglobulins $\mathrm{G}$, the sample was centrifuged for $30 \mathrm{~min}$ at $14,800 \mathrm{x} g$ at $4^{\circ} \mathrm{C}$.

Dialysis was performed using a membrane (Sigma, Dialysis Sacks) that permits a $12 \mathrm{kDa}$ exclusion limit for protein retention and ammonium sulfate release. The process was performed for 3 days in a flask with two liters of PBS $\mathrm{pH} 7.2$, with changes every $12 \mathrm{~h}$. The immunoglobulins were centrifuged at $3,700 \mathrm{x} g$ for $15 \mathrm{~min}$ at $4^{\circ} \mathrm{C}$ to remove impurities. The dialyzed material was centrifuged at $1,330 \mathrm{x}$ $g$ for $15 \mathrm{~min}$ at $4^{\circ} \mathrm{C}$ to separate the immunoglobulins. Proteins were quantified in a Metrolab 1,700 Spectrophotometer, with UV rays, at $260 \mathrm{~nm}$ and $280 \mathrm{~nm}$.

\section{Fluorescein isothiocyanate conjugation}

The fluorescein isothiocyanate (FITC) was dissolved in carbonate/bicarbonate buffer and added, drop by drop, to the immunoglobulin suspension in the proportion of $1.6 \mu \mathrm{g}$ of FITC to $1 \mathrm{mg}$ of protein, at room temperature under slow magnetic stirring. The mixture was maintained under slow magnetic stirring for $2 \mathrm{~h}$, taking care to avoid foaming.

The sample was then submitted to molecular exclusion chromatography in a Sephadex G 25 column (Sigma Aldrich). After hydrating the Sephadex with ultrapure water, it was washed five times with borate saline and transferred to a gel filtration column. The volume of the column was estimated respecting the proportion of $20 \mathrm{~mL}$ of gel for $1 \mathrm{~mL}$ of conjugate. The initial fraction (conjugate) was separated and dialyzed in borate saline for $48 \mathrm{~h}$, centrifuged at $1,330 \times \mathrm{g}$ for $10 \mathrm{~min}$ at $4^{\circ} \mathrm{C}$, aliquoted and stored at $-20^{\circ} \mathrm{C}$.

\section{Oocyst detection by direct immunofluorescence}

To determine the sensitivity of the direct immunofluorescence (DIF) using the polyclonal antibodies, the slides were adsorbed with $1,000,500,100,50,10,5$, and 1 oocyst/spot, in quintuplicate, diluted in PBS, pH 7.2. As each spot was filled with $20 \mu \mathrm{L}$, these amounts are equivalent to 50,000 to 50 oocysts $/ \mathrm{mL}$. Slides containing 1,000, 500,100 , and 10 of Giardia duodenalis cysts were prepared, also in quintuplicate, aimed at evaluating the specificity of the technique. Following the addition of oocysts, the slides were left standing at room temperature for $15 \mathrm{~min}$ for the oocysts to sediment and then incubated at $37^{\circ} \mathrm{C}$ for $1 \mathrm{~h}$, or until completely dry. Subsequently, the slides were placed in light-proof containers and frozen at $-20^{\circ} \mathrm{C}$ until use.

Immediately before use, the slides were thawed at $37^{\circ} \mathrm{C}$ for 10 to $15 \mathrm{~min}$ and submitted to three washes with PBS $\mathrm{pH}$ 7.2. The conjugate diluted in Evans's blue was added to the slides pure or in the following dilutions: $1: 1,1: 2,1: 4,1: 8,1: 16,1: 32,1: 64$, and $1: 128$. The slides were incubated in a moist chamber for $30 \mathrm{~min}$ in the dark. After performing three washes with PBS, pH 7.2, the slides were incubated at $37^{\circ} \mathrm{C}$ for $10 \mathrm{~min}$ to dry and were examined under an Olympus BX4TF fluorescence microscope.

\section{Ethical considerations}

All procedures related to managing the animals and material collection were approved by the Ethics Committee on Animal Experimentation of the Federal University of Parana (CEEA/ UFPR), protocol no. 23075.029322/2007-47, certificate 250 . 


\section{RESULTS}

The amount of protein obtained from $10^{8}$ oocysts was $2.5 \mathrm{mg} / \mathrm{mL}$ and $1.7 \mathrm{mg} / \mathrm{mL}$ for the soluble and particulate antigens, respectively. The production kinetics of anti-Cryptosporidium-specific antibodies was tested by the ELISA technique, in which 500ng of protein $/ \mathrm{mL}$ as antigen, 1:100 dilution of the serum, and 1:2,500 dilution of the conjugate were used. The cutoff point was determined by estimating the average absorbance of the negative controls plus two standard deviations, corresponding to 0.100 . Thus, samples with absorbance equal to or higher than 0.100 were considered positive. The rabbit sera collected during the experiment were titered, and all showed levels of absorbance higher than 0.100 , verifying the production of anti-Cryptosporidium antibodies (Figure 1).

The purified and FITC-conjugated anti-Cryptosporidium polyclonal antibodies tested in DIF assays detected oocysts in all replicates that contained 1,000 to 100 parasites (Figure 2). Two out of the five replicates containing 50 to 10 oocysts were positive, only one replicate with five oocysts was positive, and no sample containing only one oocyst was positive (Table 1).

No cross-reaction with Giardia duodenalis cysts was observed in any of the slide spots.

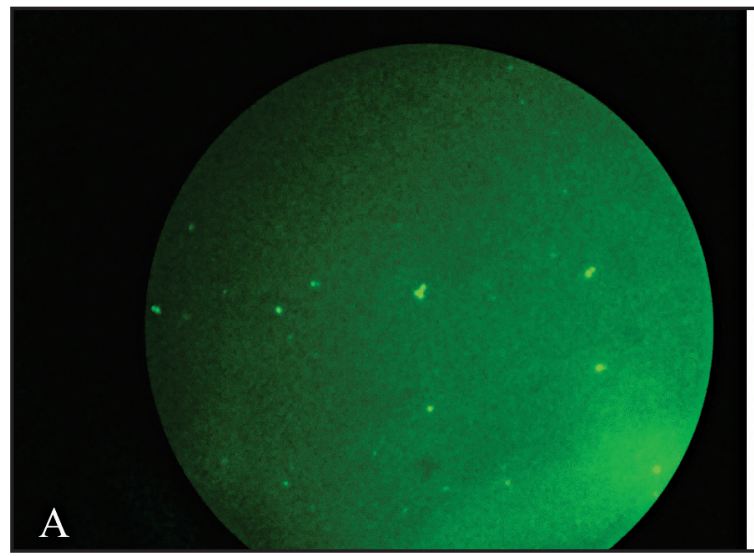

FIGURE 2 - Cryptosporidium oocysts detected by direct immunofluorescence assay using polyclonal antibodies produced by rabbit immunization. A. 200X, B. 400X

\section{DISCUSSION}

Identification of Cryptosporidium in water is impaired by the low number of oocysts and by adverse environmental factors that may alter their morphology ${ }^{1}$. Thus, techniques that can concentrate and correctly identify the parasites are required. Methods 1,622 and 1,623 of the American Environment Protection Agency ${ }^{5,6}$ are considered a reference for detecting Cryptosporidium in water. Among the several steps required to perform these methods, the final morphological identification involves the use of differential interference contrast microscopy, 4'-6-diamino-2-phenylindole (DAPI) staining, and immunofluorescence using a commercial kit. In Brazil and other developing countries, poly- or monoclonal antibodies against Cryptosporidium are not produced by national companies. Thus, the importation of immunofluorescence kits is costly for sanitation companies to monitor the parasites in water. Considering these
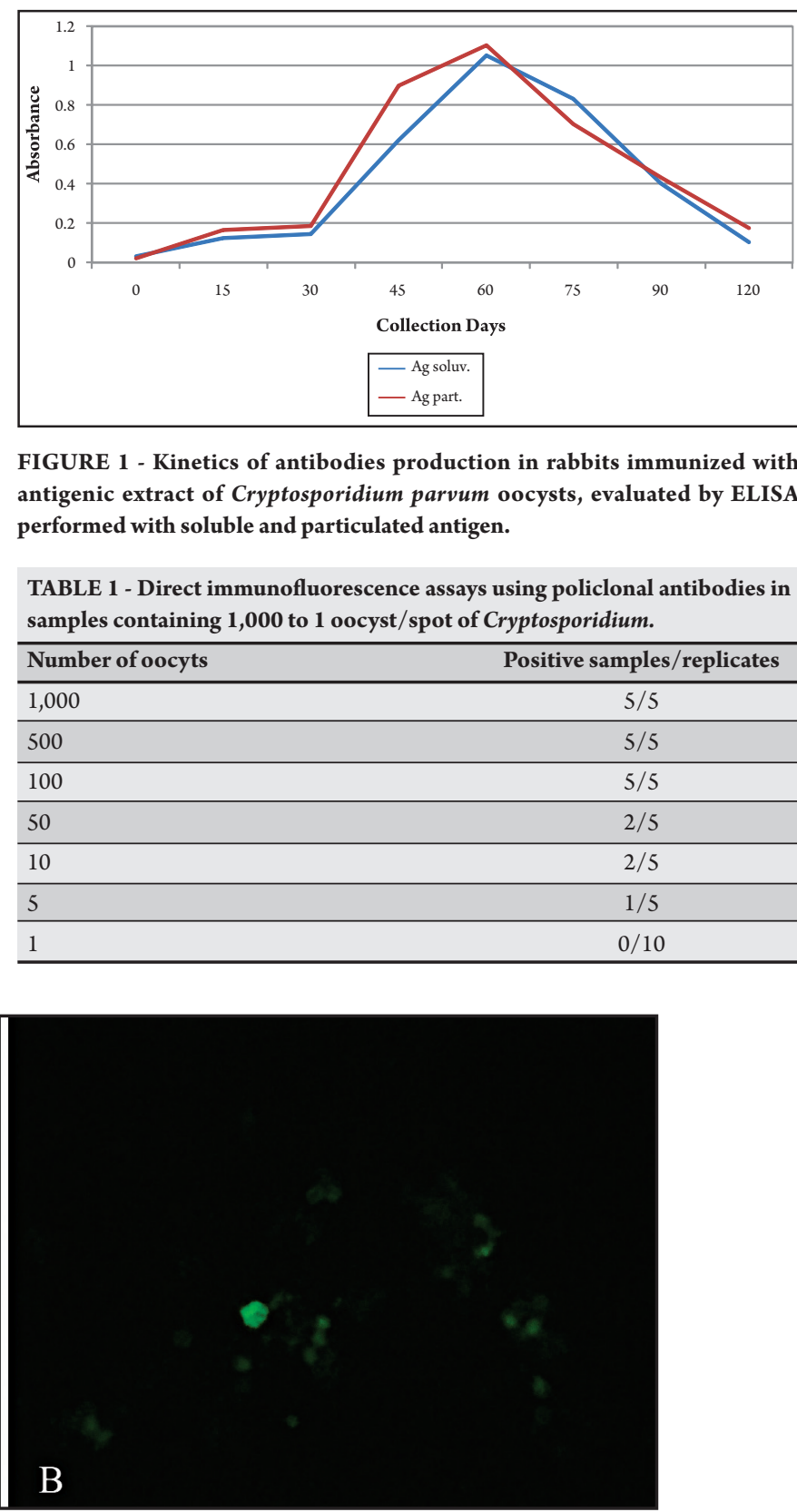

FIGURE 1 - Kinetics of antibodies production in rabbits immunized with antigenic extract of Cryptosporidium parvum oocysts, evaluated by ELISA performed with soluble and particulated antigen.

TABLE 1 - Direct immunofluorescence assays using policlonal antibodies in samples containing 1,000 to 1 oocyst/spot of Cryptosporidium.

\begin{tabular}{lc}
\hline Number of oocyts & Positive samples/replicates \\
\hline 1,000 & $5 / 5$ \\
\hline 500 & $5 / 5$ \\
\hline 100 & $5 / 5$ \\
\hline 50 & $2 / 5$ \\
\hline 10 & $2 / 5$ \\
\hline 5 & $1 / 5$ \\
\hline 1 & $0 / 10$ \\
\hline
\end{tabular}

aspects, the present work standardized a direct immunofluorescence reaction using anti-Cryptosporidium polyclonal antibodies produced by immunization in rabbits. These animals were chosen because they present greater volume compared with other animals and, consequently, produce a larger quantity of blood.

The anti-Cryptosporidium antibodies were successfully produced and used in DIF assays, which revealed sufficient sensitivity to detect 5 oocyst/spot or 250 oocysts/mL.

Cross-reactions can occur in direct immunofluorescence tests performed in water samples, as the presence of a large number of fluorescent particles may cause difficulties during the microscopic confirmation of suspect oocysts ${ }^{3,12,13}$. In the present work, the reactivity of the anti-Cryptosporidium antibodies with Giardia duodenalis cysts was tested, and no cross-reaction was observed. Despite the large morphological difference between oocysts and cysts, the intent of the specificity test was to precisely observe the presence of possible components present in the cysts that might be recognized by the anti-Cryptosporidium antibodies. 
Although some unspecific reactions do occur, the DIF is a good alternative for detecting environmental contamination by Cryptosporidium oocysts ${ }^{1}$. Moreover, the technique can be associated with DAPI staining and differential contrast microscopy, which would improve the chances of correct identification.

Eventually, the development of DIF that uses monoclonal antibodies could make it possible to indicate hosts as the source of contamination by identifying individual Cryptosporidium species, as some of these present antigenic difference ${ }^{14}$. Monoclonal antibody production involves more laborious procedures and is the next step to be developed by our group. As screening methodologies with affordable costs are demanded by sanitation companies to maintain the optimum prices of the services provided, in the present work, we believe the standardization of a DIF with polyclonal antibodies for immediate use was the best initial choice. This should be considered as the first initiative to produce inputs for immunodetection of Cryptosporidium at a national level, and the results indicated that it can be used for screening of environmental samples.

\section{CONFLICT OF INTEREST}

The authors declare that there is no conflict of interest.

\section{FINANCIAL SUPPORT}

Fundação Nacional de Saúde (Ministério da Saúde - Brasil); Conselho Nacional de Desenvolvimento Científico e Tecnológico (CNPq-Brasil).

\section{REFERENCES}

1. Cartusio-Neto R, Franco RMB. Ocorrência de oocistos de Cryptosporidium spp. e cistos de Giardia spp. em diferentes pontos do processo de tratamento de água, em Campinas, São Paulo, Brasil. Rev Hig Alim 2004; 18:52-59.

2. Xiao L, Cama V. Foodborne Parasites. Ortega YR, editor. Cryptosporidium and Cryptosporidiosis. Food Microbiol and Food Safety, Springer, New York, US; 2006. p. 57-108.

3. Rodgers MR, Flanigan DJ, Jakubowski W. Identification of algae which interfere with the detection of Giardia cysts and Cryptosporidium oocysts and a method for alleviating this interference. Appl Environ Microbiol 1995; 61:3759-3763.

4. Hashimoto A, Sugimoto H, Morita S, Hirata T. Genotyping of single Cryptosporidium oocysts in sewage by semi-nested PCR and direct sequencing. Water Res 2006; 40:2527-2532.

5. United States Environmental Protection Agency. Method 1,622-Cryptosporidium in water by filtration/IMS/FA. 821-R-97-023U.S. Washington (DC): Environmental Protection Agency Publication. U.S. Environmental Protection Agency; 1997.

6. United States Environmental Protection Agency. Method 1,623-Cryptosporidium and Giardia in water by filtration/IMS/FA. U.S. 821/R-99-006. Washington (D.C): Environmental Protection Agency Publication. U.S. Environmental Protection Agency; 1999.

7. Silva MBO. Infecção natural e experimental de Cryptosporidium em caprinos: avaliação clínica, parasitológica e da resposta humoral. [Tese]. [Belo Horizonte]: Universidade Federal de Minas Gerais; 2000. 187 p.

8. Bradford MM. A rapid and sensitive method for the quantitation of protein utilizing the protein-dye binding. Anal Biochem 1976; 72:248-254.

9. Frost FJ, Cruz de La AA, Moss DM, Curry M, Calderon RL. Comparisons of ELISA and Western blot assays for detection of Cryptosporidium antibody. Epidemiol Infect 1998; 121:205-211.

10. Fernandes NLM, Thomaz-Soccol V, Pinto SB, Minozzo JC, Oliveira CAL. Resposta imune-humoral e celular em bovinos da raça Nelore imunizados com extrato de larvas (L2 e L3) de Dermatobia hominis (Linnaeus Jr, 1781). Cienc Rural 2007; 37:789-795.
11. Penha TR. Produção e caracterização de anticorpos monoclonais anti-fragmento Fc de IgG de bovino. [Dissertação]. [Curitiba]: Universidade Federal do Paraná; $2007.98 \mathrm{p}$

12. Bull S, Chalmers R, Sturdee AP, Curry A, Kennaugh J. Cross-reaction of an antiCryptosporidium monoclonal antibody with sporocysts of Monocystis species. Vet Parasitol 1998; 77:195-197.

13. Quintero-Betancourt W, Peele ER, Rose JB. Cryptosporidium parvum and Cyclospora cayetanensis: a review of laboratory methods for detection of these waterborne parasites. J Microbiol Methods 2002; 49:209-224.

14. Sturbaum GD, Schaefer DA, Jost BH, Sterling CR, Riggs MW. Antigenic differences within the Cryptosporidium hominis and Cryptosporidium parvum surface proteins P23 and GP900 defined by monoclonal antibody reactivity. Mol Biochem Parasitol 2008; 159:138-141. 